\title{
Perinatal Data of Refugee Women from the Gynaecology Department of Charité University Hospital Berlin Compared with German Federal Analysis
}

\section{Erhebung perinataler Daten von geflüchteten Frauen von der Frauenklinik der Charité - Universitätsmedizin Berlin im Vergleich zur bundesdeutschen Auswertung}

\section{(ㄷ) (1)}

Authors

Ola Ammoura ${ }^{1}$, Jalid Sehouli ${ }^{1}$, Christine Kurmeyer ${ }^{3}$, Rolf Richter ${ }^{1}$, Nadja Kutschke ${ }^{1}$, Wolfgang Henrich ${ }^{2}$, Melisa Guelhan Inci ${ }^{1}$

\author{
Affiliations \\ 1 Charité - Universitätsmedizin Berlin, Klinik für Gynäko- \\ logie, Campus Virchow-Klinikum, Berlin, Germany \\ 2 Charité - Universitätsmedizin Berlin, Klinik für \\ Geburtsmedizin, Berlin, Germany \\ 3 Charité - Universitätsmedizin Berlin, Frauen- und \\ Gleichstellungsbeauftragte, Berlin, Germany
}

Key words

pregnancy, complications, refugees, Germany, infants

Schlüsselwörter

Schwangerschaft, Komplikationen, Flüchtlinge, Deutschland, Neugeborene

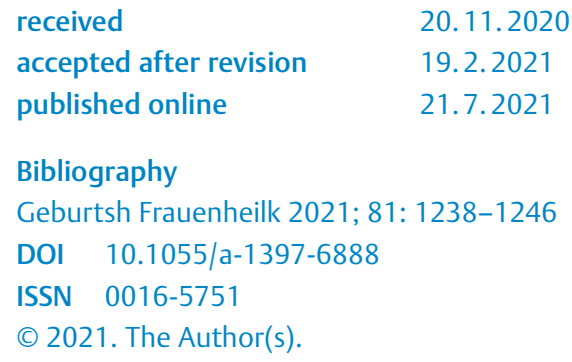

This is an open access article published by Thieme under the terms of the Creative Commons Attribution-NonDerivative-NonCommercial-License, permitting copying and reproduction so long as the original work is given appropriate credit. Contents may not be used for commercial purposes, or adapted, remixed, transformed or built upon. (https://creativecommons.org/licenses/by-nc-nd/4.0/)

Georg Thieme Verlag KG, Rüdigerstraße 14,

70469 Stuttgart, Germany

Correspondence

Melisa Guelhan Inci

Universitätsmedizin Berlin, Klinik für Gynäkologie, Campus Virchow-Klinikum

Augustenburger Platz 1, 13353 Berlin, Germany guelhan.inci@charite.de

\author{
Deutsche Version unter: \\ https://doi.org/10.1055/a-1397-6888
}

\section{ABSTRACT}

Introduction The aim of this study was to record the perinatal data of refugee women at Charité Hospital, Berlin, and to evaluate possible differences in pre-, peri- and postnatal outcomes compared with indigenous women.

Material and Methods All pregnant women who gave birth in the period from 1 January 2014 to 30 September 2017 and were registered at least once in the hospital as "refugee" were included in the analysis. The data recorded from the refugee women were compared with the perinatal data of the German Federal obstetric analysis for the year 2016, which was published by the IQTIG (Institut für Qualitätssicherung und Transparenz im Gesundheitswesen [Institute for Quality Assurance and Transparency in Healthcare]).

Results The analysis comprised 907 refugee women and 928 infants (21 twin pregnancies). Pregnant refugee women were significantly younger than the pregnant women from the Federal analysis (birth before the age of $30: 66$ vs. $41 \%$, $\mathrm{p}<0.001$, RR: 1.6, 95\% Cl: 62.9-69.2). They had a history both of more pregnancies ( $\geq 3$ pregnancies: 29.4 vs. $13.4 \%$, $\mathrm{p}<0.001$, RR: 2.2, 95\% Cl: 26.4-32.5) and of more miscarriages (>2 miscarriages: 9.7 vs. $5.9 \%, p<0.001$, RR: $1.6,95 \%$ $\mathrm{Cl}$ : 7.9-11.8) and more often had a history of suffering from psychological stress (11.1 vs. $4.1 \%$, p $<0.001$, RR: $2.70,95 \%$ $\mathrm{Cl}$ : 9.2-13.4). There were more premature births (10.3 vs. $3.0 \%, p<0.001$, RR: 3.36, 95\% Cl: 8.4-12.4), post-term pregnancies (8.5 vs. $0.5 \%, \mathrm{p}<0.001$, RR: $15.4,95 \% \mathrm{Cl}: 6.7-10.5$ ), and cases of postpartum anaemia ( 28.7 vs. $22.0 \%, p<0.001$, RR: $1.30,95 \% \mathrm{Cl}: 25.7-31.7)$ and puerperal endometritis ( 1 vs. $0.2 \%, p=0.006$, RR: $4.3,95 \% \mathrm{Cl}: 0.5-1.9$ ) compared with the Federal analysis. The neonatal outcome showed an increased rate of hypotrophy ( 11 vs. $7 \%, p<0.001$, RR: 1.6 , 
95\% Cl: 9.1-13.2), more stillbirths (0.7 vs. $0.2 \%, p=0.006$, RR: 3, 95\% Cl: 0.2-1.4) and increased congenital malformations (2.8 vs. $0.4 \%, \mathrm{p}<0.001, \mathrm{RR}: 3,95 \% \mathrm{Cl}: 0.2-1.4$ ).

Conclusion Both refugee women and their infants showed significant differences. Despite the average younger age of the pregnant refugee women, the rates of premature birth and stillbirth and congenital malformations were significantly more frequent. More intensive antenatal screening with differentiated foetal organ diagnostics including psychosomatic care could contribute to early identification and prompt diagnosis. As regards the postpartum anaemia and puerperal endometritis, which occur more often in refugee women, midwife engagement and an improvement in the living situation in homes and accommodation facilities could be of great importance.

\section{ZUSAMMENFASSUNG}

Einleitung Ziel dieser Arbeit war die Erhebung perinataler Daten von geflüchteten Frauen an der Berliner Charité und die Evaluation von möglichen Unterschieden bezüglich prä-, peri, und postnataler Ausgänge im Vergleich zu den einheimischen Frauen.

Material und Methodik Alle Schwangeren, die im Zeitraum vom 1. Januar 2014 bis 30. September 2017 geboren haben und mindestens einmal im Klinikum als „Flüchtling“ registriert worden sind, wurden in die Auswertung eingeschlossen. Die erhobenen Daten der geflüchteten Frauen wurden verglichen mit den Perinataldaten der Bundesauswertung der Geburtshilfe aus dem Jahr 2016, die durch die IQTIG (Institut für Qualitätssicherung und Transparenz im Gesundheitswesen) veröffentlicht wurde.

Ergebnisse Die Auswertung erfolgte mit 907 geflüchteten Frauen und 928 Neugeborenen (21 Zwillingsschwangerschaf- ten). Geflüchtete Schwangere waren signifikant jünger als die Schwangeren aus der Bundesauswertung (Geburt vor dem 30. Lebensjahr: 66 vs. $41 \%, p<0,001$, RR: 1,6, 95\%-KI: 62,9$69,2)$. Sie hatten sowohl mehr Schwangerschaften ( $\geq 3$ Schwangerschaften: 29,4 vs. $13,4 \%, p<0,001$, RR: 2,2, 95\%-KI: 26,4-32,5) als auch mehr Aborte in der Anamnese (> 2 Aborte: 9,7 vs. 5,9\%, p<0,001, RR: 1,6, 95\%-KI: 7,9-11,8) und litten anamnestisch häufiger unter psychischer Belastung (11,1 vs. 4,1\%, p<0,001, RR: 2,70, 95\%-KI: 9,2-13,4). Es zeigten sich mehr Frühgeburten (10,3 vs. 3,0\%, p<0,001, RR: 3,36, $95 \%-K I: 8,4-12,4)$, Terminüberschreitungen ( 8,5 vs. $0,5 \%$, p<0,001, RR: 15,4, 95\%-KI: 6,7-10,5), postpartale Anämien (28,7 vs. $22,0 \%, p<0,001$, RR: 1,30, 95\%-KI: 25,7-31,7) sowie eine Endometritis puerperalis ( 1 vs. $0,2 \%, p=0,006$, RR: 4,3, 95\%-KI: 0,5-1,9) im Vergleich zur Bundesauswertung. Das neonatale Outcome zeigte eine erhöhte Rate von Hypotrophien ( 11 vs. $7 \%, p<0,001$, RR: 1,6, 95\%-KI: 9,1-13,2), mehr Totgeburten ( 0,7 vs. $0,2 \%, p=0,006$, RR: $3,95 \%-K I: 0,2-1,4)$ und vermehrte kongenitale Fehlbildungen $(2,8$ vs. $0,4 \%$, p<0,001, RR: 3, 95\%-KI: 0,2-1,4).

Schlussfolgerung Sowohl geflüchtete Frauen als auch ihre Neugeborenen wiesen signifikante Unterschiede auf. Trotz des durchschnittlich jüngeren Alters der geflüchteten Gebärenden waren die Raten der Früh- und Totgeburten und die angeborenen Fehlbildungen signifikant häufiger. Eine intensivere Schwangerenvorsorge mit differenzierter Organdiagnostik des Feten inklusiver psychosomatischer Betreuung könnten zur Früherkennung und frühzeitige Diagnosestellung dienen. Hinsichtlich der postpartalen Anämie und der Endometritis puerperalis, die häufiger bei geflüchteten Frauen auftreten, könnte der Hebammeneinsatz sowie die Verbesserung der Wohnsituationen in Heimen und Unterkünften von groBer Bedeutung sein.

\section{Introduction}

With about 1.3 million refugees registered by the Central Register of Foreign Nationals (AZR) on the reference date 30.09.2019, Germany was the country that accepted the second-largest number of refugees worldwide in 2019 [1]. 43.5\% of the refugees are female, and about $44.5 \%$ of these are of reproductive age (between 15 and 50 years) [2]. Both socioeconomic factors such as education, income and also access to healthcare and living conditions are decisive for the health situation of the refugees [3]. Women represent a particularly vulnerable group, as, in addition to the aforementioned factors, they suffer from a lack of reproductive healthcare, undernutrition or unwanted pregnancies [4]. For pregnant women or breast-feeding women, exposure to chemical, biological and nuclear weapons used in war regions is particularly dangerous [4].

A number of studies have shown an association between flight, poor socioeconomic circumstances and inadequate perinatal care with poorer pre- and postnatal outcome $[3,5,6]$.

Previous studies of pregnant refugee women show an increased risk for pregnancy complications such as gestational dia- betes, HIV infection, oligohydramnios, prematurity, caesarean section and postpartum anaemia [3, 5-9]. In addition, the infants have a poorer neonatal outcome, which is characterised by lower Apgar scores and lower birth weight $[5,7,9]$. Refugees also avail more rarely of health screening [8].

Overall, there are only a few data on the current health status and care need of pregnant refugee women in Germany. To prepare the structures for the needs of refugee women, we need articles that review the status quo first.

The aim of this study was to record perinatal data of refugee women at Charité Hospital, Berlin, and to evaluate possible differences in pre-, peri- and postnatal outcomes compared with indigenous women.

\section{Methods}

\section{Data collection}

The data were obtained from the department of obstetrics of Berlin's Charité hospital, Virchow Clinic and Mitte campuses, where a total of 5526 births were recorded for 2019, making it one of the 


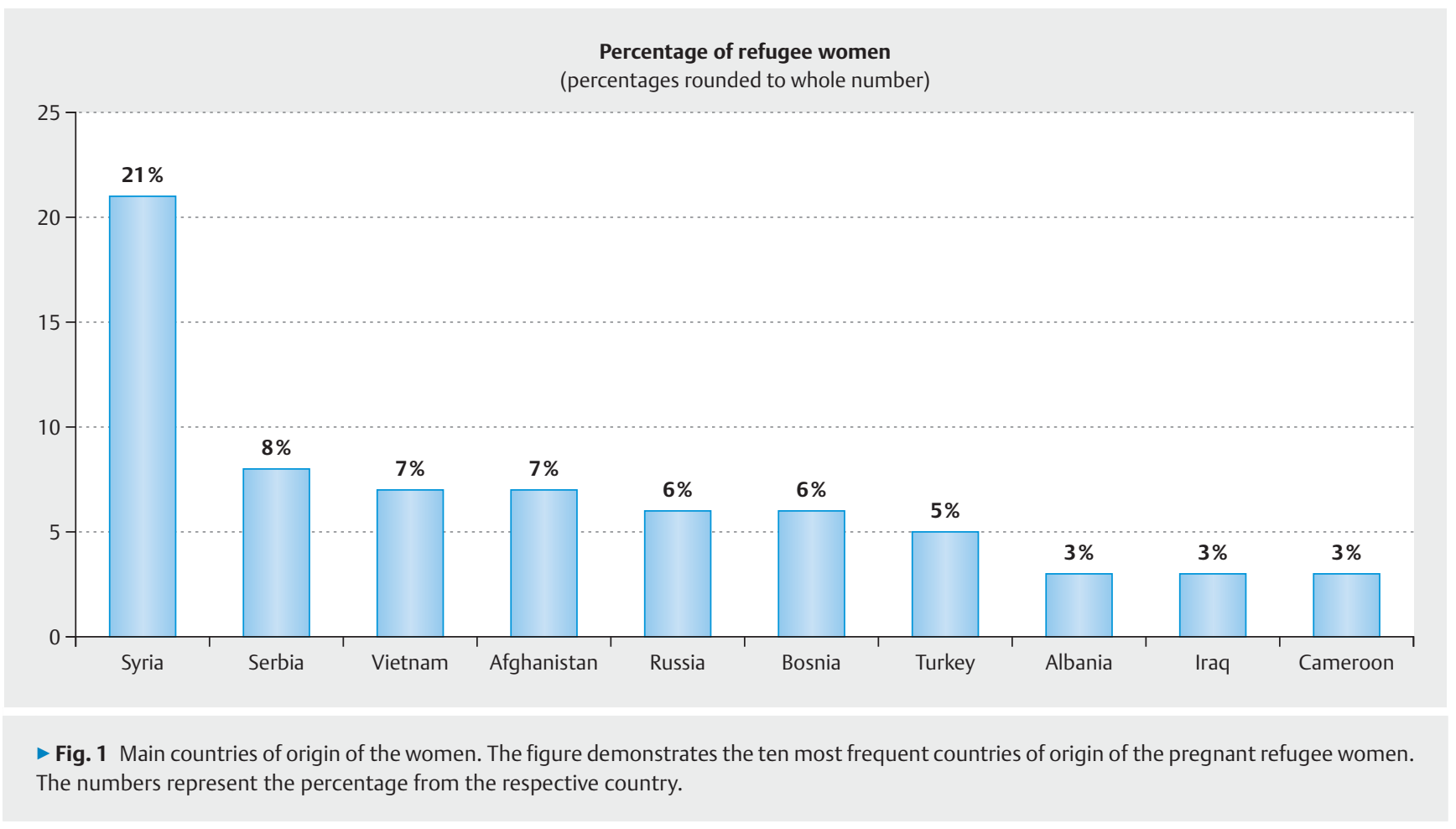

biggest hospitals in Germany [10]. All pregnant women who delivered in the period from 1 January 2014 to 30 September 2017 and were registered as "refugee" at least once in the Charité hospital's information system were included in the analysis.

The variables selected for data collection were based on a review of the previous literature and on the obstetric quality assurance of the Institute for Quality Assurance and Transparency in Healthcare (IQTIG). The aim of this quality assurance is to improve obstetric care in Germany. Pre-, peri- and postnatal data across Germany are analysed and compared using certain quality indicators.

The following variables were selected.

Region and country of origin, maternal age, BMI before pregnancy, allergies, number of pregnancies (gravida) and births (para), gestational risks, gestational age, delivery mode, primary or secondary section, indications for section, induction of delivery, episiotomy, perinatal and peripartum complications, intrauterine foetal death, congenital malformations, birth weight, Apgar score after $5 \mathrm{~min}$, neonatal transfer to the paediatric unit.

The information about the pregnant women is based on maternity log entries, internal hospital test results and data on the obstetric outcome, which can be found both in the electronic patient record and in the birth reports. Missing data were excluded when the respective variable was analysed.

The obtained data were compared with the German Federal Obstetric Analysis for the year 2016, which was produced by the Institute for Quality Assurance and Transparency in Healthcare (IQTIG) [11]. The dataset of the Federal analysis includes the perinatal data of all births that took place in a hospital in Germany. In 2016 this included 741 hospitals and 758783 births.

\section{Statistical analysis}

The obtained data were entered in anonymised form in a SPSS database (IBM, PASW, version 24.0). We compared the observed results from our cohort with the expected values from the German Federal statistics for 2016. The difference between the expected and the observed results was tested for significance with the $X^{2}$ test. P-values $<0.05$ were regarded as significant. In addition, a relative risk (RR) with $95 \%$ confidence intervals $(95 \% \mathrm{Cl})$ was calculated for all results. Missing data (below 5\%) were excluded from the analysis.

\section{Results}

\section{Maternal demographic and clinical characteristics}

907 refugee women with 928 infants (21 twin pregnancies) were included in the analysis: $20.8 \%$ (189) of the refugees came from Syria and a further $8 \%$ (73) from Serbia, followed by $7.2 \%$ (65) from Vietnam and 6.5\% (59) from Afghanistan.

The main countries of origin of the women included in the study are listed in $\mathbf{F i g .} \mathbf{1}$.

The refugee women showed a significantly younger maternal age $(66 \%$ were under 30 years vs. $41 \%$ in the comparator cohort, $\mathrm{p}<0.001)$. Moreover, the number of very young mothers ( $<18$ years) was 3.6 times higher among the refugees than in the German Federal analysis (19 vs. 5.3).

- Fig. 2 compares the two groups with regard to maternal age.

The proportion of refugee women with three or more pregnancies was significantly higher than in the Federal analysis (29.4 vs. $13.4 \%$, $p<0.001)$. Refugee women had a history of more than two miscarriages significantly more often (9.7 vs. $5.9 \%$, 


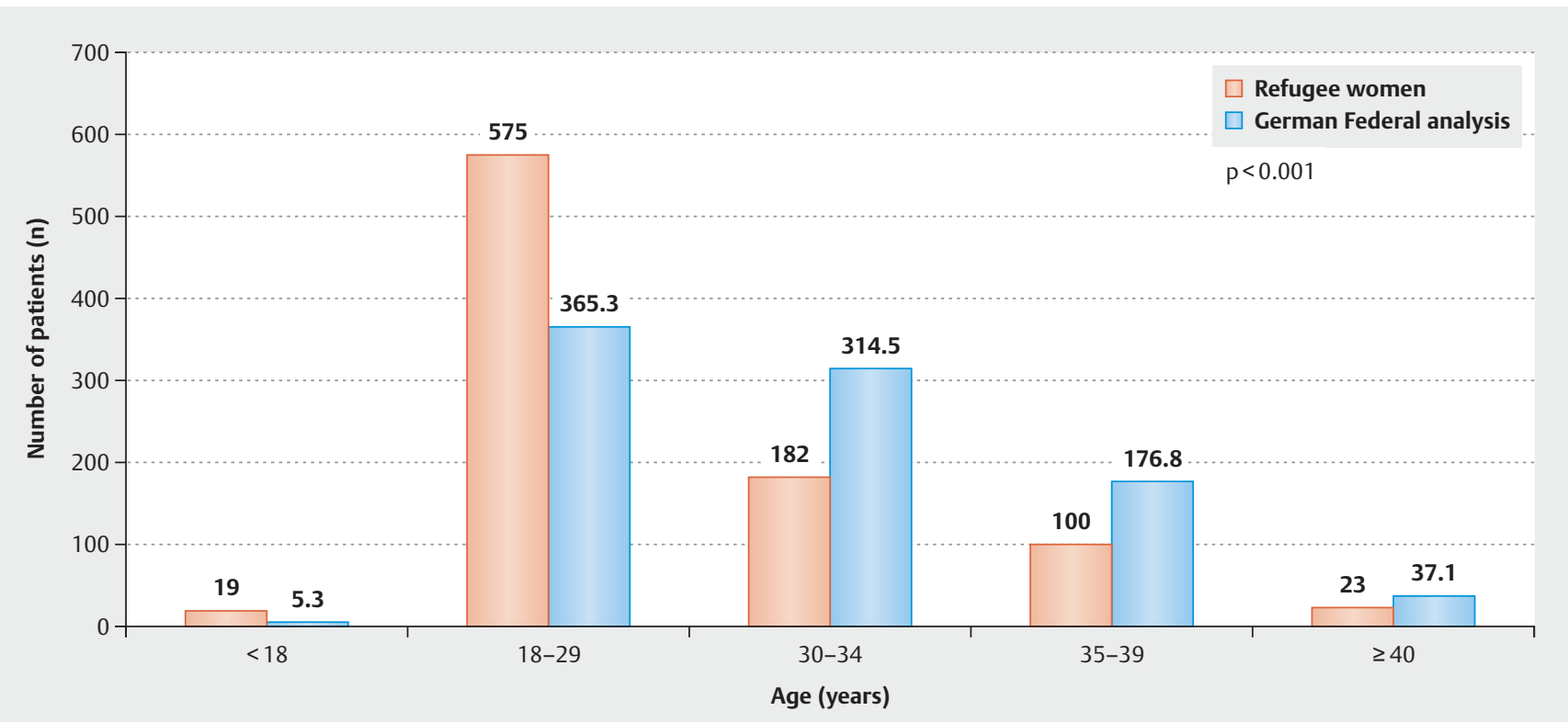

- Fig. 2 Maternal age of the refugee women compared with the German Federal analysis for 2016. The figure shows the differences in maternal age among the refugee women and the women from the Federal analysis. The $\mathrm{X}$ axis demonstrates the age of the women and the $\mathrm{Y}$ axis the number of patients (n).

$\mathrm{p}<0.001)$, had a more frequent history of psychological stress (11.1 vs. $4.1 \%, p<0.001)$ and had a higher percentage of multiparas (4.4 vs. $0.9 \%, \mathrm{p}<0.001)$.Moreover, they had more sections in their previous history (20 vs. $13.6 \%, \mathrm{p}<0.001)$. > Table 1 shows the perinatal data of the refugee women compared with the Federal analysis (IQTIG).

\section{Obstetric and perinatal data}

The rate of premature birth was significantly increased in the refugee women compared with the Federal analysis (10.3 vs. $3.0 \%$, $\mathrm{p}<0.001)$. Post-term pregnancy also occurred much more often among the refugees $(8.5$ vs. $0.5 \%, p<0.001)$. The most frequent indication for section in both groups was "previous section" but this indication was twice as high among the refugees as in the women in the Federal analysis (61.7 vs. $30.6 \%, p<0.001)$. > Table 2 compares the perinatal results of the refugee women with those of the Federal analysis.

Among the postpartum complications, the incidence of puerperal endometritis was 4.3 times higher in the refugee women (1 vs. $0.2 \%, p=0.006$ ) and they had a history of anaemia more often than the women in the Federal analysis ( 28.7 vs. $22.0 \%$, $\mathrm{p}<0.001)$.

\section{Neonatal outcome}

The infants of the refugee women had a significantly higher rate of low birth weight ( 11 vs. $7 \%, p<0.001)$. The infants of the refugee women had congenital malformations much more often than the infants in the Federal analysis $(2.8$ vs. $0.4 \%, p<0.001)$. The rates of stillbirth $(0.7$ vs. $0.2 \%, p=0.006)$ and transfer of the infants to a paediatric unit ( 13.3 vs. $11 \%, p=0.028$ ) were higher in the refugees. A comparison of the neonatal outcomes of the refugees and the Federal analysis group is shown in > Table 3.

\section{Discussion}

To our knowledge, this article is the first to analyse the peri- and postpartum data of refugee women in Germany to this extent. We examined both maternal and neonatal characteristics of refugee women and compared these with the German Federal obstetric analysis for the year 2016. Our results show significant differences in the perinatal data of refugee women compared with the Federal analysis. Pregnant refugee women were significantly younger, had both more pregnancies and more frequent miscarriages in their history and more often had a history of suffering from psychological stress. Increased rates of premature birth and postterm pregnancy were also seen. There was a greater postpartum incidence of puerperal endometritis and anaemia in refugee women. The neonatal outcome showed more low birth weights, more frequent stillbirths and more congenital malformations.

Our data also show a markedly younger maternal age in refugee women, including more underage pregnant women. A retrospective study from Istanbul, Turkey, compared 300 pregnant Syrian women with a similarly-sized control group of pregnant Turkish women and also showed significantly younger maternal age among the refugees [8]. Two other retrospective studies from Jordan [5] and Toronto [3] yielded similar results. Another study by our working group showed, in addition, that only $53 \%$ of refugee women who wished to avoid pregnancy used contraceptive methods. $34 \%$ of them used the unreliable method of coitus interruptus [12]. This could help to explain the younger maternal age and the frequent pregnancies. 
- Table 1 Maternal demographic and clinical characteristics of the refugee women compared with the perinatal data of the German Federal obstetric analysis from the year 2016 recorded by the IQTIG (Institute for Quality Assurance and Transparency in Healthcare).

\begin{tabular}{|c|c|c|c|c|c|c|}
\hline \multirow[t]{2}{*}{ Maternal characteristics } & \multicolumn{3}{|c|}{ Observed } & \multirow{2}{*}{$\begin{array}{l}\text { Expected } \\
(\%)\end{array}$} & \multirow[t]{2}{*}{$\mathbf{R R}$} & \multirow[t]{2}{*}{ p-value* } \\
\hline & $\mathbf{n}$ & $\%$ & $95 \% \mathrm{Cl}$ & & & \\
\hline \multicolumn{7}{|l|}{ Maternal age } \\
\hline . $<18$ years & 19 & 2.1 & $1.3-3.3$ & 0.6 & 3.57 & \multirow[t]{5}{*}{$\mathrm{p}<0.001$} \\
\hline - 18-29 years & 575 & 64 & $60.7-67.1$ & 40.6 & 1.56 & \\
\hline - 30-34 years & 182 & 20.2 & $17.7-23$ & 35 & 0.57 & \\
\hline - 35-39 years & 100 & 11.1 & $9.1-13.4$ & 19.7 & 0.56 & \\
\hline - $\geq 40$ years & 23 & 2.6 & $1.6-3.8$ & 4.1 & 0.61 & \\
\hline \multicolumn{7}{|l|}{ Parity } \\
\hline - Primiparous & 293 & 32.6 & $29.6-35.8$ & 47.8 & 0.68 & \multirow[t]{2}{*}{$p<0.001$} \\
\hline - Multiparous & 605 & 67.4 & $64.2-70.4$ & 52.28 & 1.29 & \\
\hline \multicolumn{7}{|c|}{ Body mass index (BMI) before pregnancy } \\
\hline . $<20$ & 84 & 13.6 & $11-16.5$ & 13.3 & 1.01 & \multirow[t]{4}{*}{$p=0.001$} \\
\hline - $20-<25$ & 277 & 44.7 & $40.7-48.7$ & 48.3 & 0.92 & \\
\hline - $25-<30$ & 183 & 29.6 & $26-33.3$ & 23.2 & 1.27 & \\
\hline . $\geq 30$ & 76 & 12.3 & $9.8-15.1$ & 15.2 & 0.80 & \\
\hline \multicolumn{7}{|l|}{ Allergies } \\
\hline - yes & 68 & 7.6 & $5.9-9.5$ & 23 & 0.32 & $p<0.001$ \\
\hline \multicolumn{7}{|l|}{ Gestational risk } \\
\hline - at least one gestational risk & 585 & 64.5 & $61.3-67.6$ & 34.6 & 1.86 & $\mathrm{p}<0.001$ \\
\hline \multicolumn{7}{|l|}{ Miscarriage history } \\
\hline - $\geq 2$ previous miscarriages & 88 & 9.7 & $7.9-11.8$ & 5.9 & 1.64 & $p<0.001$ \\
\hline \multicolumn{7}{|l|}{ Smoker } \\
\hline - yes & 18 & 2 & $1.2-3.1$ & 5.5 & 0.36 & $\mathrm{p}<0.001$ \\
\hline \multicolumn{7}{|l|}{ Psychological stress } \\
\hline - yes & 101 & 11.1 & $9.2-13.4$ & 4.1 & 2.70 & $p<0.001$ \\
\hline \multicolumn{7}{|l|}{ Pregnant women $<18$ years } \\
\hline - yes & 18 & 2 & $1.2-3.1$ & 0.7 & 2.95 & $\mathrm{p}<0.001$ \\
\hline \multicolumn{7}{|l|}{ Pregnant women $>35$ years } \\
\hline - yes & 124 & 13.7 & $11.5-16$ & 17.3 & 0.78 & $p=0.004$ \\
\hline \multicolumn{7}{|l|}{ Multipara } \\
\hline - yes & 40 & 4.4 & $3.2-6$ & 0.9 & 5.0 & $p<0.001$ \\
\hline \multicolumn{7}{|l|}{ History of dead/damaged child } \\
\hline - yes & 34 & 3.8 & $2.6-5.2$ & 1.5 & 2.55 & $\mathrm{p}<0.001$ \\
\hline \multicolumn{7}{|l|}{ History of caesarean section } \\
\hline - yes & 181 & 20 & $17.4-22.7$ & 13.6 & 1.47 & $p<0.001$ \\
\hline \multicolumn{7}{|l|}{ Diagnosed anaemia } \\
\hline - yes & 3 & 0.3 & $0-1$ & 1.6 & 0.21 & $p=0.003$ \\
\hline \multicolumn{7}{|l|}{ Urinary tract infection } \\
\hline - yes & 3 & 0.3 & $0-1$ & 0.4 & 0.89 & $p=0.84$ \\
\hline \multicolumn{7}{|l|}{ Gestational diabetes } \\
\hline - yes & 59 & 6.5 & $5-8.3$ & 5.4 & 1.20 & $p=0.14$ \\
\hline
\end{tabular}


- Table 2 Obstetric and perinatal data of the refugee women compared with the perinatal data of the German Federal obstetric analysis from the year 2016 recorded by the IQTIG (Institute for Quality Assurance and Transparency in Healthcare).

\begin{tabular}{|c|c|c|c|c|c|c|}
\hline \multirow[t]{2}{*}{ Maternal characteristics } & \multicolumn{3}{|c|}{ Observed } & \multirow{2}{*}{$\begin{array}{l}\text { Expected } \\
(\%)\end{array}$} & \multirow[t]{2}{*}{$\mathbf{R R}$} & \multirow[t]{2}{*}{ p-value* } \\
\hline & $\mathbf{n}$ & $\%$ & $95 \% \mathrm{Cl}$ & & & \\
\hline \multicolumn{7}{|l|}{ Gestational age } \\
\hline . <28 weeks & 12 & 1.3 & $0.7-2.3$ & 0.6 & 2.27 & \multirow[t]{5}{*}{$\mathrm{p}<0.001$} \\
\hline - $18-<32$ weeks & 15 & 1.7 & $0.9-2.8$ & 0.9 & 1.85 & \\
\hline - $32-<37$ weeks & 65 & 7.3 & $5.6-9.2$ & 7.2 & 1.01 & \\
\hline - 37-41 weeks & 728 & 81.3 & $78.5-83.8$ & 90.8 & 0.89 & \\
\hline . >41 weeks & 76 & 8.5 & $6.7-10.5$ & 0.6 & 15.41 & \\
\hline \multicolumn{7}{|l|}{ Delivery mode } \\
\hline - Caesarean section & 297 & 32.4 & $29.4-35.5$ & 32 & 1.01 & \multirow[t]{3}{*}{$p=0.56$} \\
\hline - Spontaneous & 549 & 59.9 & $56.6-63.1$ & 61.1 & 0.98 & \\
\hline - Assisted vaginal & 71 & 7.7 & $6.1-9.7$ & 6.9 & 1.12 & \\
\hline \multicolumn{7}{|l|}{ Premature birth (<37 weeks) } \\
\hline " yes & 92 & 10.3 & $8.4-12.4$ & 3.1 & 3.36 & $p<0.001$ \\
\hline \multicolumn{7}{|l|}{ Post-term pregnancy } \\
\hline - yes & 76 & 8.5 & $6.7-10.5$ & 0.6 & 15.4 & $p<0.001$ \\
\hline \multicolumn{7}{|l|}{ Episiotomy for vaginal delivery } \\
\hline - yes & 82 & 13.5 & $10.9-16.5$ & 20.2 & 0.66 & $\mathrm{p}<0.001$ \\
\hline \multicolumn{7}{|c|}{ Premature rupture of the membranes } \\
\hline " yes & 237 & 26.1 & $23.3-29.1$ & 24.4 & 1.07 & $p=0.21$ \\
\hline \multicolumn{7}{|l|}{ Perinatal complications } \\
\hline - Prepartum haemorrhage & 3 & 0.3 & $0.7-1$ & 1.5 & 0.22 & $p=0.004$ \\
\hline - Placenta praevia & 6 & 0.7 & $0.2-1.4$ & 0.3 & 2 & $p=0.08$ \\
\hline - Oligohydramnios & 1 & 0.1 & $0-0.6$ & 0.9 & 0.12 & $p=0.02$ \\
\hline - Placental insufficiency & 3 & 0.3 & $0.7-1$ & 2.5 & 0.15 & $p<0.001$ \\
\hline - Isthmocervical insufficiency & 10 & 1.1 & $0.5-2$ & 1.4 & 0.79 & $p=0.47$ \\
\hline - Premature labour & 2 & 0.2 & $0-2.7$ & 2.1 & 0.10 & $p<0.001$ \\
\hline \multicolumn{7}{|l|}{ Postpartum complications } \\
\hline - Haemorrhage > $1000 \mathrm{ml}$ & 11 & 1.2 & $0.6-2.2$ & 1.5 & 0.81 & $p=0.49$ \\
\hline - Delayed wound healing & 2 & 0.2 & $0-2.7$ & 0.1 & 2.2 & $p=0.27$ \\
\hline - Laparotomy & 1 & 0.1 & $0-0.6$ & 0.1 & 1 & $p=0.98$ \\
\hline - Eclampsia & 2 & 0.2 & $0-2.7$ & 0.1 & 3.14 & $p=0.08$ \\
\hline - Sepsis & 1 & 0.1 & $0-0.6$ & 0 & 2.5 & $p=0.39$ \\
\hline - Puerperal endometritis & 9 & 1 & $0.5-1.9$ & 0.2 & 4.28 & $p=0.006$ \\
\hline - Postpartum anaemia & 260 & 28.7 & $25.7-31.7$ & 22 & 1.30 & $p<0.001$ \\
\hline${ }^{*} x^{2}$ test & & & & & & \\
\hline
\end{tabular}

Refugee women reported a history of psychological stress during pregnancy more often, at $11 \%$, than women in the Federal analysis (4\%). As is apparent from a review of perinatal health outcomes of refugee women, a lack of familial and social support and stressful life experiences are the most frequent reasons for perinatal psychological health disorders $[13,14]$. These stressful factors can in turn be associated with the increased rate of miscarriage among the refugees. A meta-analysis from 2017 shows that psychological stress before and during pregnancy can increase the risk for miscarriage by about $42 \%$ [15].
In addition, our study shows a markedly increased rate of premature births among the refugee women. A systematic review from 2009 compared the perinatal data among immigrants and native inhabitants of Western industrialised countries and showed that migrants from Asia and Sub-Saharan Africa have a higher risk for premature births [16]. The fact that $20.8 \%$ of the refugee women in our cohort come from a current war region (Syria) confirms the results of a retrospective analysis from 2008, which showed an increased rate of premature births during the war in Bosnia and Herzegovina [17]. Other factors that probably play a 
- Table 3 Neonatal outcome of the refugee women compared with the perinatal data of the German Federal obstetric analysis from the year 2016 recorded by the IQTIG (Institute for Quality Assurance and Transparency in Healthcare).

\begin{tabular}{|c|c|c|c|c|c|c|}
\hline \multirow[t]{2}{*}{ Characteristics } & \multicolumn{3}{|c|}{ Observed } & \multirow{2}{*}{$\begin{array}{l}\text { Expected } \\
(\%)\end{array}$} & \multirow[t]{2}{*}{$\mathbf{R R}$} & \multirow[t]{2}{*}{ p-value* } \\
\hline & $\mathbf{n}$ & $\%$ & $95 \% \mathrm{Cl}$ & & & \\
\hline \multicolumn{7}{|l|}{ Birth weight } \\
\hline - LBW (500-2500) & 101 & 11 & $9.1-13.2$ & 7 & 1.57 & $p=0.002$ \\
\hline \multicolumn{7}{|l|}{ Apgar after 5 minutes } \\
\hline . $<7$ & 22 & 2.4 & $1.5-3.6$ & 1.2 & 2 & $p=0.053$ \\
\hline \multicolumn{7}{|l|}{ Transfer to neonatal unit } \\
\hline - yes & 119 & 13.3 & $11.2-15.7$ & 11 & 1.20 & $p=0.028$ \\
\hline \multicolumn{7}{|l|}{ Malformations } \\
\hline - at least one malformation & 25 & 2.8 & $1.8-4$ & 0.4 & 7.57 & $p<0.001$ \\
\hline \multicolumn{7}{|l|}{ Foetal death } \\
\hline - yes & 6 & 0.7 & $0.2-1.4$ & 0.2 & 3 & $p=0.006$ \\
\hline
\end{tabular}

part in prematurity are stress, malnutrition and lack of integration in the health system [18]. A cohort study from Sweden published in 2014 supports the hypothesis that stress due to war and migration represents a risk for premature birth in the short term. The results showed a higher rate of prematurity in the first year after migration compared with subsequent years [18].

As regards post-term pregnancies, our results conflict with the aforementioned case control study from Istanbul, as these postterm pregnancies occurred markedly more often in the pregnant refugee women in our analysis than in native pregnant women [8]. A study from Washington in which the perinatal data of Somali migrants were compared with those of women born in the USA showed a similar tendency with post-term pregnancy being 9 times more frequent in the migrant women [9]. One reason might be inaccuracy in determining the expected date of delivery due to the lateness of routine ultrasound scans [9].

The postpartum data showing a markedly increased rate of puerperal endometritis and postpartum anaemia represent important information. The results could be attributed to the poor socioeconomic circumstances, poor hygiene environment and inadequate perinatal care in accommodation facilities. Midwife support in the puerperium is an important part of the postpartum care structure and refugee women should also be entitled to this. Associations between bacterial vaginosis in pregnancy, which is more common in refugee women, and postpartum endometritis have been found, which in turn could be linked with poor hygiene in accommodation facilities [19-21].

As shown previously in many studies, low birth weight was significantly more frequent among the infants of refugee women and migrants $[3,5,22,23]$. Low birth weight is an important indicator for infant mortality and morbidity [24]. There are various known risk factors that can influence the infant's birth weight. Young maternal age (15-19 years) [24,25], psychosocial stress $[24,26]$, low socioeconomic status [24,27], maternal malnutrition, absent or poor prenatal care and pregnancies in rapid suc- cession [24] are some of the risk factors present in refugee mothers.

Our analysis shows a three times higher rate of stillbirths among the refugees compared with births in the Federal analysis. It should be mentioned here that this rate could be examined more precisely with a better differentiated control group as the Federal analysis contains all births including those of migrants in whom an increased stillbirth rate has been shown in the literature $[28,29]$. Our study indicates, in any case, that this rate is higher among refugees compared with all other groups in society. Thus, our results support the conclusion of the systematic review by Gissler et al. from 2010 that refugees represent the most vulnerable group as regards stillbirths [29]. The causes for this are manifold, including low birth weight in the infants and the increased rate of congenital malformation in combination with delayed or absent prenatal screening coupled with different religious and cultural attitudes regarding a possible indication for termination of pregnancy [29].

The increased rate of congenital malformations in our cohort is also reflected in other studies $[22,23,30]$. Nybo Andersen et al. have discussed three possible causes for this:

1. The socioeconomic disadvantage of most migrants,

2. Consanguinity in many migrant groups and

3. Poor utilisation and quality of care during pregnancy [31].

The language barrier possibly leads to lower utilisation of prenatal screening. Malformations are occasionally diagnosed early but do not result in termination of pregnancy because of cultural and religious attitudes.

Various measures such as the use of interpreters and communication of these results to healthcare staff and to the relevant authorities or socially committed organisations could reduce the negative influence of flight on maternal and infant outcomes. J. Spallek et al from Berlin compared the perinatal data of women of Turkish origin and of German women in two periods (19931997 and 2003-2007). The differences between the two groups 
with regard to perinatal data diminished. After 10 years, no differences were found any longer in the rates of stillbirth, premature birth and foetal malformations [32].

Our study has a few limitations because of our selected method. It is a retrospective analysis, which by its nature could lead to bias. Nevertheless, we succeeded in performing a comprehensive analysis of numerous parameters of maternal and infant outcome among refugee women and delivering important results. A further limitation of our study is the lack of a control group of our own. The comparison was with the Federal analysis from the year 2016 with a heterogeneous group. The strength of this presentation in turn is the high number of refugee women compared with recent studies from other countries $[3,5,6,8]$. Moreover, this study is one of the first in Germany that has dealt with the perinatal health of refugee women. These results deliver initial information about the obstetric care of refugee women and can serve as the basis of further studies.

\section{Conclusion}

Both refugee women and their infants showed significant differences. Despite the younger average age of the pregnant refugee women, the rates of premature and stillbirth and congenital malformations were significantly more frequent. More intensive screening of pregnant women with differentiated organ diagnostics of the foetus including psychosomatic care could serve for early identification and prompt diagnosis. As regards postpartum anaemia and puerperal endometritis, which occur more often in refugee women, use of midwives and an improvement of the living situation in homes and accommodation facilities could be of great importance. These findings should be considered in clinical practice and in the healthcare system. Informing refugee women about the different risk factors with appropriate language competence and communicating these results to medical staff as well as integration of further approaches for intercultural competence can potentially lead to a sustained improvement in the care of refugee women in Germany.

\section{Conflict of Interest}

The authors declare that they have no conflict of interest.

\section{References}

[1] Mediendienst Integration. Flucht \& Asyl | Zahl der Flüchtlinge. Accessed January 09, 2018 at: https://mediendienst-integration.de/migration/ flucht-asyl/zahl-der-fluechtlinge.html

[2] BAMF - Bundesamt für Migration und Flüchtlinge. Aktuelle Zahlen (12/ 2019). Accessed July 14, 2020 at: https://www.BAMF.de/SharedDocs/ Anlagen/DE/Statistik/AsylinZahlen/aktuelle-zahlen-dezember-2019. html?nn=284722

[3] Kandasamy T, Cherniak R, Shah R et al. Obstetric risks and outcomes of refugee women at a single centre in Toronto. J Obstet Gynaecol Can 2014; 36: 296-302. doi:10.1016/S1701-2163(15)30604-6

[4] Al Gasseer N, Dresden E, Keeney GB et al. Status of women and infants in complex humanitarian emergencies. J Midwifery Womens Health 2004; 49: 7-13. doi:10.1016/j.jmwh.2004.05.001
[5] Alnuaimi K, Kassab M, Ali R et al. Pregnancy outcomes among Syrian refugee and Jordanian women: a comparative study. Int Nurs Rev 2017; 64: 584-592. doi:10.1111/inr.12382

[6] Reese Masterson A, Usta J, Gupta J et al. Assessment of reproductive health and violence against women among displaced Syrians in Lebanon. BMC Womens Health 2014; 14: 25. doi:10.1186/1472-6874-14-25

[7] David M, Borde T, Brenne S et al. Comparison of Perinatal Data of Immigrant Women of Turkish Origin and German Women - Results of a Prospective Study in Berlin. Geburtshilfe Frauenheilkd 2014; 74: 441-448. doi:10.1055/s-0034-1368489

[8] Erenel H, Aydogan Mathyk B, Sal V et al. Clinical characteristics and pregnancy outcomes of Syrian refugees: a case-control study in a tertiary care hospital in Istanbul, Turkey. Arch Gynecol Obstet 2017; 295: 4550. doi:10.1007/s00404-016-4188-5

[9] Johnson EB, Reed SD, Hitti J et al. Increased risk of adverse pregnancy outcome among Somali immigrants in Washington state. Am J Obstet Gynecol 2005; 193: 475-482. doi:10.1016/j.ajog.2004.12.003

[10] Accessed October 15, 2020 at: https://www.hebnews.de/documents/ 10181/0/Milupa+Geburtenliste+2019/6d6f3000-1f67-417a-bcbe$539 f a 0 b d 4 f 94$

[11] IQTIG. Bundesauswertung zum Erfassungsjahr 2016, Geburtshilfe. Accessed January 24, 2018 at: https://iqtig.org/downloads/ergebnisse/ bundesauswertung/2016/indirekte_verfahren/QSKH_16n1-GEBH_2016 _BUAW_V02_2017-07-12.pdf

[12] Inci MG, Kutschke N, Nasser S et al. Unmet family planning needs among female refugees and asylum seekers in Germany - is free access to family planning services enough? Results of a cross-sectional study. Reproductive Health 2020. doi:10.1186/s12978-020-00962-3

[13] Heslehurst N, Brown H, Pemu A et al. Perinatal health outcomes and care among asylum seekers and refugees: a systematic review of systematic reviews. BMC Med 2018. doi:10.1186/s12916-018-1064-0

[14] Schouler-Ocak M. Study on Female Refugees. Berlin: Psychiatrische Universitätsklinik Charité; 2017

[15] Qu F, Wu Y, Zhu Y-H et al. The association between psychological stress and miscarriage: A systematic review and meta-analysis. Sci Rep 2017; 7: 1731. doi:10.1038/s41598-017-01792-3

[16] Gagnon AJ, Zimbeck M, Zeitlin J et al. Migration to western industrialised countries and perinatal health: a systematic review. Soc Sci Med 2009; 69: 934-946. doi:10.1016/j.socscimed.2009.06.027

[17] Fatusić Z, Kurjak A, Grgić $G$ et al. The influence of the war on perinatal and maternal mortality in Bosnia and Herzegovina. J Matern Fetal Neonatal Med 2005; 18: 259-263. doi:10.1080/147670500198501

[18] Liu C, Urquia M, Cnattingius S et al. Migration and preterm birth in war refugees: a Swedish cohort study. Eur J Epidemiol 2014; 29: 141-143. doi:10.1007/s10654-013-9877-9

[19] Watts DH, Krohn MA, Hillier SL et al. Bacterial vaginosis as a risk factor for post-cesarean endometritis. Obstet Gynecol 1990; 75: 52-58

[20] McGregor ]A, French Jl. Bacterial vaginosis in pregnancy. Obstet Gynecol Surv 2000; 55 (5 Suppl 1): S1-S19. doi:10.1097/00006254-20000500100001

[21] Romanik M, Martirosian G. [Frequency, diagnostic criteria and consequences of bacterial vaginosis in pregnant women]. Przegl Epidemiol 2004; 58: 547-553

[22] Arnetz B, Drutchas A, Sokol R et al. 1991 Gulf War Exposures and Adverse Birth Outcomes. US Army Med Dep J 2013; 58-65

[23] Keasley J, Blickwedel J, Quenby S. Adverse effects of exposure to armed conflict on pregnancy: a systematic review. BM] Global Health 2017; 2: e000377. doi:10.1136/bmjgh-2017-000377

[24] Valero de Bernabé J, Soriano T, Albaladejo R et al. Risk factors for low birth weight: a review. Eur J Obstet Gynecol Reprod Biol 2004; 116: 315. doi:10.1016/j.ejogrb.2004.03.007 
[25] Ziadeh S. Obstetric outcome of teenage pregnancies in North Jordan. Arch Gynecol Obstet 2001; 265: 26-29. doi:10.1007/s004040000121

[26] Orr ST, James SA, Miller CA et al. Psychosocial stressors and low birthweight in an urban population. Am J Prev Med 1996; 12: 459-466

[27] Lund R, Modvig J, Hilden J et al. Risk of low birthweight in social districts of Copenhagen. Scand J Public Health 1999; 27: 89-93

[28] Vik ES, Nilsen RM, Aasheim V et al. Country of first birth and neonatal outcomes in migrant and Norwegian-born parous women in Norway: a population-based study. BMC Health Serv Res 2020; 20: 540. doi:10.1186/s12913-020-05415-y

[29] Gissler M, Alexander S, Macfarlane A et al. Stillbirths and infant deaths among migrants in industrialized countries. Acta Obstet Gynecol Scand 2009; 88: 134-148. doi:10.1080/00016340802603805
[30] Makhseed M, el-Tomi N, Moussa MA et al. Post-war changes in the outcome of pregnancy in Maternity Hospital, Kuwait. Med Confl Surviv 1996; 12: 154-167. doi:10.1080/13623699608409273

[31] Nybo Andersen A-M, Gundlund A, Villadsen SF. Stillbirth and congenital anomalies in migrants in Europe. Best Pract Res Clin Obstet Gynaecol 2016; 32: 50-59. doi:10.1016/j.bpobgyn.2015.09.004

[32] Spallek J, Lehnhardt J, Reeske A et al. Perinatal outcomes of immigrant women of Turkish, Middle Eastern and North African origin in Berlin, Germany: a comparison of two time periods. Arch Gynecol Obstet 2014; 289: 505-512. doi:10.1007/s00404-013-2986-6 